Original article

\title{
The effects of dietary phytoestrogens on aromatase activity in human endometrial stromal cells
}

\author{
Katie M. EDMUnds ${ }^{\mathrm{a}}$, Alison C. Holloway ${ }^{\mathrm{a}}$, Denis J. CRANKSHAW ${ }^{\mathrm{a}}$, \\ Sanjay K. AGARWAL ${ }^{b}$, Warren G. FOSTER ${ }^{a *}$ \\ a Reproductive Biology Division, Department of Obstetrics and Gynecology, McMaster University, \\ Hamilton, Ontario, USA \\ b Department of Reproductive Medicine, University of California, San Diego, California, USA
}

(Received 14 January 2005; accepted 26 May 2005)

\begin{abstract}
Dietary phytoestrogens have been reported to inhibit aromatase activity in placental microsomes, but the effects in the human endometrium are unknown. Aromatase, the rate-limiting enzyme in the conversion of androgens to estrogens, has recently been shown to be expressed in the endometrium of women with endometriosis and is thought to play a role in the pathophysiology of this disease. Therefore, the objective of this study was to screen dietary phytoestrogens for their ability to inhibit aromatase activity in human endometrial stromal cells (ESC) and identify potential novel therapeutic agents for the treatment of endometriosis. The inhibition of aromatase activity by direct interaction with the dietary phytoestrogens genistein, daidzein, chrysin, and naringenin was tested in a cell free assay. Furthermore, test compound effects on aromatase activity in ESC cultures were also examined. Genistein and daidzein were inactive in the human recombinant aromatase assay whereas naringenin and chrysin inhibited aromatase activity. However, genistein ( $1 \mathrm{nM}$ to $1 \mathrm{mM})$ stimulated aromatase activity in ESC whereas other phytoestrogens had no effect. Immunopositive aromatase cells were demonstrated in genistein-treated ESC but not in untreated control cultures. Taken together, our data suggest that genistein can increase aromatase activity in ESC likely via increased enzyme expression.
\end{abstract}

phytoestrogens / endometriosis / aromatase / genistein / endometrium

\section{INTRODUCTION}

Cytochrome $\mathrm{P} 450$ aromatase $\left(\mathrm{P}^{4} 50_{\mathrm{AROM}}\right)$ is the rate limiting enzyme that catalyzes the conversion of androstenedione and testosterone to estrone and $17 \beta$-estradiol, respectively. While the ovaries are the primary source of estrogen in the body, local production of estrogen by other tissues has also been demonstrated in estrogen depend- ent diseases such as breast cancer $[1,2]$ and endometriosis [3-5]. Endometriosis is a common gynecologic disorder that is characterized by the presence of endometrial glands and stroma outside of the uterine cavity. Endometriosis is an estrogen dependent disease $[7,8]$ that affects approximately $14 \%$ of all women of reproductive age, and $30-50 \%$ of infertile women [9]. Local production of estrogens by ectopic endometrial

\footnotetext{
* Corresponding author: fosterw@mcmaster.ca
} 
implants in women with endometriosis may explain treatment failures and the persistence of recalcitrant endometriosis in postmenopausal women [6]. Therefore targeted inhibition of local estrogen production in endometriotic lesions by inhibition of aromatase activity may have a place in the management of this disease. As endometriosis is the leading cause of hospitalization for gynecologic surgery [10], thus novel, safe and effective treatment options are urgently needed.

Phytoestrogens are a class of plant estrogens that include isoflavones, flavones, flavonones and several mycotoxins such as coumestrol and zeralanone. Phytoestrogens are thought to have health benefits such as providing protection against breast cancer development [11, 12] and are potentially useful in the management of menopausal symptoms [13, 14]. Dietary factors such as phytoestrogens have been shown to inhibit aromatase activity $[15,16]$ without altering plasma estrogen concentrations [17]. Therefore, therapeutic use of phytoestrogens may be of benefit to women with endometriosis.

Soy-based foods have high phytoestrogen content of which genistein is the dominant isoflavone [18]. Chrysin, a flavone found in the plant Passiflora coerula and naringenin, a flavonone found in citrus fruits, have been shown to inhibit aromatase activity in hepatocytes and placental microsomes in vitro $[19,20]$. However, the effects of these compounds on aromatase expression are unknown. Furthermore, aromatase expression is regulated via different promoter regions in a tissue specific manner [21] and thus the effects of phytoestrogens on endometrial aromatase expression and activity are also unknown. Therefore, the objective of this study was to screen several phytoestrogens for their ability to directly inhibit aromatase activity and to determine the effect of dietary phytoestrogens on aromatase expression and activity in human endometrial stromal cells. Genistein and daidzein, the dominant phytoestrogens in the diet, together with chrysin and naringenin, two phytoestrogens previously shown to inhibit aromatase activity were selected as the test compounds for this study. We hypothesized that phytoestrogens will inhibit aromatase activity in endometrial stromal cell cultures and thus potentially provide a novel therapeutic option that is both natural and effective in the management of endometriosis.

\section{MATERIALS AND METHODS}

\subsection{Cell-free assay}

The ability of the test compounds to interact directly with the enzyme to alter aromatase activity was investigated in a cell free assay by modification of the fluorescence assay described previously [22], using human recombinant aromatase expressed in insect cell microsomes (CYP19 suprasomes BD Gentest Biosciences, Woburn, USA) and $0.25 \mu \mathrm{M}$ dibenzylfuorescein (BD Gentest Biosciences, Woburn, USA) as the substrate. The ability of test compounds $(1 \mathrm{pM}-100 \mu \mathrm{M}$ in $0.1 \mathrm{M}$ potassium phosphate buffer $\mathrm{pH}$ 7.4) to inhibit aromatase enzyme activity $(0.4$ pmol aromatase/well was examined by incubation in the presence of cofactors $(40 \mu \mathrm{M}$ NADP, $100 \mu \mathrm{M}$ Glucose-6-phosphate, $100 \mu \mathrm{M}$ $\mathrm{MgCl}_{2}$ ) and DMSO (1\%). Assays were performed in a 96-well black walled culture plate (Becton Dickinson, Franklin Lakes USA) in a total volume of $202 \mu \mathrm{L}$. Reactions were started by addition of $50 \mu \mathrm{L}$ of prewarmed $\left(37{ }^{\circ} \mathrm{C}\right)$ enzyme to the prewarmed plates. Blank wells contained $50 \mu \mathrm{L}$ of buffer in place of the enzyme. The plate was incubated at $37^{\circ} \mathrm{C}$ for $1 \mathrm{~h}$ and preliminary experiments showed that enzyme activity was linear up to $90 \mathrm{~min}$. The reaction was stopped by the addition of $75 \mu \mathrm{L}$ of $2 \mathrm{M} \mathrm{NaOH}$ to each well. Fluorescence was measured using a PerkinElmer HTS 7000 Bio Assay Reader at an excitation wavelength $=485 \mathrm{~nm}$ and emission $=535 \mathrm{~nm}$. Fluorescein (Sigma Aldrich, Oakville, Canada) was used as the standard. 
Non-linear least-squares regression analysis was used to fit inhibition curves to the equation:

$$
\begin{aligned}
\mathrm{E}= & \mathrm{E}_{\min }+ \\
& \left(\mathrm{E}_{\max }-\mathrm{E}_{\min }\right) /\left(1+10^{-\mathrm{pIC}_{50}-\log \mathrm{C}}\right)
\end{aligned}
$$

where $\mathrm{E}_{\max }$ and $\mathrm{E}_{\min }$ are the maximum and minimum effects of the test compound, respectively. $\mathrm{pIC}_{50}$ is the negative $\log$ of the molar concentration of the compound that produces $50 \%$ inhibition of enzyme and $\log$ $\mathrm{C}$ is the molar concentration of the compound that produces the effect $\mathrm{E}$. $\mathrm{IC}_{50}$ values were converted to $\mathrm{K}_{\mathrm{i}} \mathrm{s}$ using the Cheng Prusoff equation [23]:

$$
\left.\mathrm{Ki}=\mathrm{IC}_{50} /\left(1+\mathrm{S} / \mathrm{K}_{\mathrm{m}}\right)\right)
$$

where $\mathrm{S}$ is the substrate concentration and $\mathrm{K}_{\mathrm{m}}$ is the Michaelis constant for the enzyme. The $\mathrm{K}_{\mathrm{m}}$ and maximum velocity $\left(\mathrm{V}_{\max }\right)$ of the enzyme reactions were determined under the same conditions as described for inhibition experiments except that the substrate concentration varied between 0 and $0.4 \mu \mathrm{M}$. Data for these experiments were fit by non-linear least-squares regression to:

$$
\mathrm{V}=\left(\mathrm{V}_{\max } \times \mathrm{S}\right) /\left(\mathrm{K}_{\mathrm{m}}+\mathrm{S}\right)
$$

where $\mathrm{V}$ is the reaction velocity at substrate concentration $\mathrm{S}$.

\subsection{Endometrial stromal cell culture}

Endometrial biopsies were obtained from eighteen women aged 27-44 (mean $( \pm \mathrm{SD})$ of $38.3 \pm 6.0$ years) undergoing benign gynecologic surgery at McMaster University Medical Centre. Informed consent was obtained from each patient by a research nurse and all procedures were carried out in accordance with approval of the McMaster University Research Ethics Board. Among the eighteen patients included in this study, eleven had a laparoscopic diagnosis of endometriosis and seven did not have any evidence of pelvic endometriosis. None of the study subjects had received endocrine therapy in the previous six months before surgery. Endometrial tis- sue (1-2 g) obtained at hysterectomy was rinsed in Hanks' balanced salt solution (HBSS) containing 200 units $\cdot \mathrm{mL}^{-1}$ penicillin, $0.2 \mathrm{mg} \cdot \mathrm{mL}^{-1}$ streptomycin and $0.5 \mu \mathrm{g} \cdot \mathrm{mL}^{-1}$ amphotericin B (Sigma Aldrich, Oakville Canada) to remove blood and debris. Separation of the endometrial stromal cells was performed as previously described [24]. Briefly, the tissue was minced into $1 \mathrm{~mm}^{3}$ fragments and digested for $2.5 \mathrm{~h}$ at $37^{\circ} \mathrm{C}$ in medium containing collagenase type IA (2 mg.mL $\mathrm{mL}^{-1}$, Sigma-Aldrich, Oakville, Canada). After digestion, the remaining tissue fragments were mechanically dispersed and the dispersed cells were filtered through a $100 \mu \mathrm{m}$ and subsequently a $40 \mu \mathrm{m}$ cell strainer (Becton Dickson, Franklin Lakes, USA). Centrifugation (10 min, $725 \times$ $g$ ) was used to pellet the cells after which time they were resuspended in $3 \mathrm{~mL}$ of plating media [DMEM:F12, 4\% FBS, 1\% ITS+ and $1 \%$ antibiotic antimycotic solution (100 units $\cdot \mathrm{mL}^{-1}$ penicillin, $0.1 \mathrm{mg} \cdot \mathrm{mL}^{-1}$ streptomycin and $0.25 \mathrm{~g} \cdot \mathrm{mL}^{-1}$ amphotericin B (Sigma Aldrich, Oakville, Canada)]. Red blood cells were removed by layering the cell suspension over $3 \mathrm{~mL}$ of FicollPaque PLUS (Amersham Biosciences, Uppsala, Sweden) in a sterile $15 \mathrm{~mL}$ polypropylene tube. The solution was centrifuged for $10 \mathrm{~min}$ at $400 \times \mathrm{g}$. The media/ Ficoll interface layer containing the stromal cells was plated into 48 well Falcon tissue culture plates (Becton Dickson, Franklin Lakes, USA) at a density of 200000 cells/ well $/ 0.5 \mathrm{~mL}$. Media was changed after $48 \mathrm{~h}$ and the cells were treated after $96 \mathrm{~h}$ in culture, when the cells were near confluence. Purity of the cell preparation was confirmed by immunostaining for vimentin (mesenchymal cell marker) and cytokeratin (epithelial cell marker) as described below.

\subsection{Cell treatment and aromatase activity assay}

Cells were washed twice in HBSS and incubated for a minimum of $1 \mathrm{~h}$ in serum-free DMEM-F12 containing 100 units $\cdot \mathrm{mL}^{-1}$ penicillin, $0.1 \mathrm{mg} \cdot \mathrm{mL}^{-1}$ streptomycin and 
$0.25 \mu \mathrm{g} \cdot \mathrm{mL}^{-1}$ amphotericin B (Sigma Aldrich, Oakville, Canada) prior to treatment for $24 \mathrm{~h}$ with increasing log concentrations $\left(10^{-9}\right.$ $10^{-4} \mathrm{M}$ ) of genistein, daidzein, naringenin or chrysin (Sigma Aldrich, Oakville, Canada) diluted in serum free media. To examine the role of estrogen receptor mediated effects, the cells were also treated with genistein in the presence of a non-selective estrogen receptor antagonist (ICI 182,780; Tocris, Ellisville, USA). After $24 \mathrm{~h}$, the treatment media was removed and replaced with $500 \mu \mathrm{L}$ of $\left[1 \beta^{3} \mathrm{H}\right]$-androstenedione $\left[2.5 \mu \mathrm{Ci} \cdot \mathrm{mL}^{-1}\right]$ (Perkin Elmer, Boston, USA) in DMEM-F12 (containing 100 units $\cdot \mathrm{mL}^{-1}$ penicillin, $0.1 \mathrm{mg} \cdot \mathrm{mL}^{-1}$ streptomycin and $0.25 \mu \mathrm{g} \cdot \mathrm{mL}^{-1}$ amphotericin B) for $4 \mathrm{~h}$ at $37^{\circ} \mathrm{C}$.

Aromatase activity was assayed using a radiometric technique that quantifies the incorporation of tritium from $\left[1 \beta^{3} \mathrm{H}\right]-$ androstenedione into ${ }^{3} \mathrm{H}$-labeled water as previously described [25]. Briefly, aromatase activity was determined by transferring $300 \mu \mathrm{L}$ of the incubation medium to glass tubes, adding $300 \mu \mathrm{L}$ of dextran coated activated charcoal $\left(250 \mathrm{mg} \cdot \mathrm{mL}^{-1}\right.$, BD Biosciences, Oakville, Canada) to each tube and incubating for $2 \mathrm{~h}$ at $4^{\circ} \mathrm{C}$. The samples were then centrifuged $(15 \mathrm{~min}$, $2500 \times g$ ) and the tritiated water content was determined by counting the supernatant in $5 \mathrm{~mL}$ of scintillation fluid (Aqueous Counting Scintillant, Amersham, England) in a liquid scintillation counter. To control for variation in the number of cells in each well, the aromatase activity was normalized to the cell protein content in each well as determined by the Bradford method. Due to variation in basal aromatase activity between patients, normalized aromatase activity was converted to a percentage of the control level for each culture. The aromatase assay is based on the release of tritiated water and the specificity of the assay was determined by co-incubation with 4-hydroxyandrostendione an irreversible inhibitor of the catalytic activity of aromatase [26] to block the formation of tritiated water.

\subsection{Immunocytochemistry}

Cells were seeded into 8 well Lab-Tek chamber slides (BD Biosciences, Oakville, Canada) at a density of 200000 cells/well/ $0.5 \mathrm{~mL}$. Media was changed after $48 \mathrm{~h}$ and the cells were treated with genistein $\left(10^{-6}\right)$ after $96 \mathrm{~h}$ in culture. After $24 \mathrm{~h}$ of treatment, the cells were fixed in $10 \%$ neutral buffered formalin, washed in PBS, and endogenous peroxidase activity was quenched by incubating the cells in $3 \%$ hydrogen peroxide (in methanol) for $5 \mathrm{~min}$. The cells were washed in PBS, incubated with the primary antibodies (Dako Diagnostics, Mississauga, Canada) for cytokeratin (1:50), and vimentin (1:50) for $1 \mathrm{~h}$ at room temperature and immunostaining was identified using EnVision (Dako Diagnostics, Mississauga, Canada) with diaminobenzidine (SigmaAldrich, Oakville, Canada) as the chromogen. The cells were counterstained with Carazzi hematoxylin. For negative controls, the cells were incubated with non-immune serum in place of the primary antibodies. To stain for the presence of aromatase in the genistein treated cultures and untreated controls, immunohistochemistry was performed on the chamberslides using a primary monoclonal mouse antibody against human aromatase (1:50 Serotec, Raleigh, USA). Immunostaining was identified with the avidin-biotin-peroxidase technique using the Vectastain kit (Vector Laboratories, Burlington, Canada) with diaminobenzadine as the chromogen and Carazzi hematoxylin as a counter stain.

\subsection{Statistical analyses}

Data were analyzed for equal variance and normal distribution. An effect of treatment on ESC aromatase activity was tested using a one-way analysis of variance (ANOVA) and differences between doses were determined using the Tukey multiple comparison method. A $p$ value $<0.05$ was considered to be statistically significant for all procedures used. 


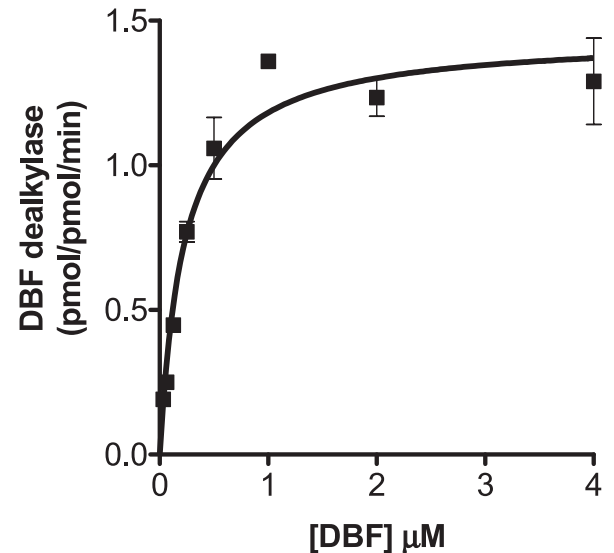

Figure 1. Michaelis-Menten plot of the dibenzyfluorescein deakylase activity of recombinant human aromatase determined as described in materials and methods. Points represent means and standard errors of triplicates within a single experiment. $\mathrm{K}_{\mathrm{m}}$ and $\mathrm{V}_{\max }$ values from this experiment were $0.22 \mu \mathrm{M}$ and $1.4 \mathrm{pmol} / \mathrm{pmol} / \mathrm{min}$, respectively.

\section{RESULTS}

\subsection{Recombinant human aromatase activity}

Aromatase activity in the presence of increasing substrate yielded a $\mathrm{K}_{\mathrm{m}}$ of $0.26 \mu \mathrm{M}$ $\left(\mathrm{pK}_{\mathrm{m}}=6.6 \pm 0.2\right)$ and $\mathrm{a} \mathrm{V}_{\text {max }}$ of $2.2 \pm 1 \mathrm{pmol}$ fluorescein released per mol enzyme per minute (Fig. 1). Naringenin $(\mathrm{Ki}=0.3 \mu \mathrm{M})$ and chrysin $(\mathrm{Ki}=1 \mu \mathrm{M})$ were potent inhibitors of recombinant human aromatase whereas genistein and daidzein were weak (Ki > $50 \mu \mathrm{M}$ ) inhibitors (Fig. 2).

\subsection{Aromatase activity after phytoestrogen treatment of endometrial stromal cells}

Immunocytochemical staining for cells of mesenchymal origin and epithelial cells illustrated that our cultures consisted of

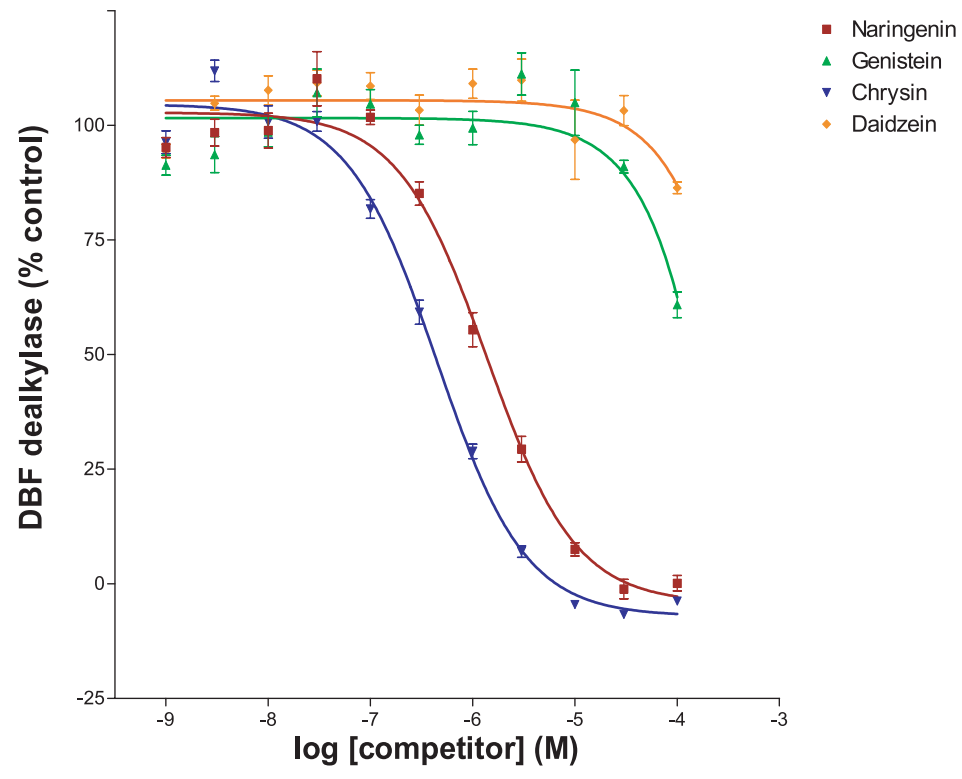

Figure 2. Human recombinant aromatase activity as indicated by fluorimetrically quantified DBF dealkylase after treatment with naringenin, chrysin, genistein and dadizein. Each data point is the mean $( \pm$ SEM) from three separated experiments. Naringenin and chrysin were effective inhibitors of the enzyme with $\mathrm{Ki}=0.3$ and $1.0 \mu \mathrm{M}$, respectively, while genistein and daidzein were ineffective as shown by a $\mathrm{Ki}>50 \mu \mathrm{M}$. 


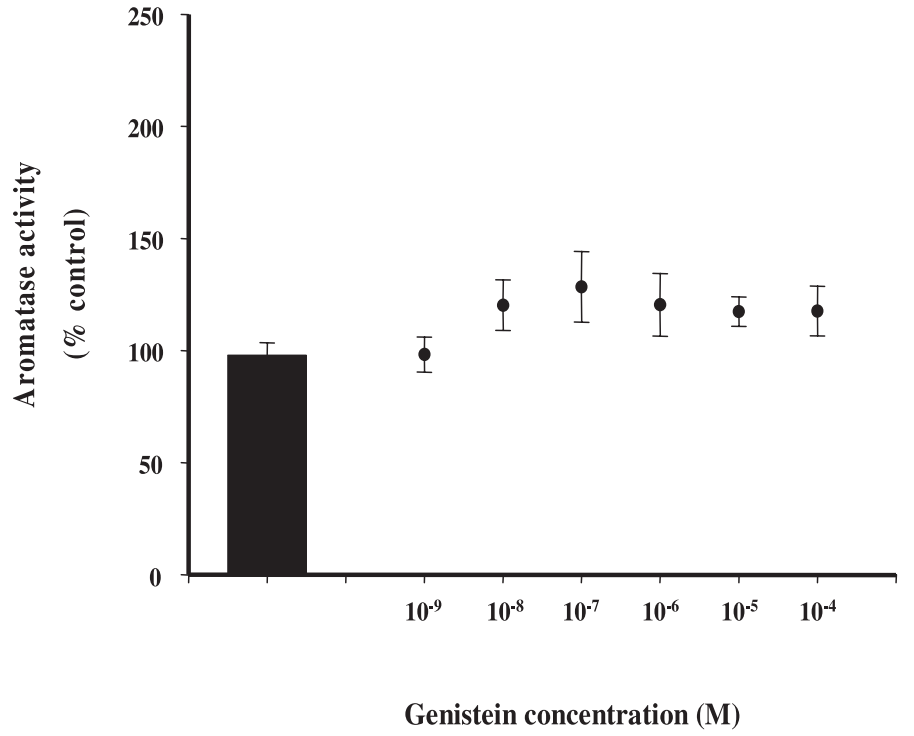

Figure 3. Aromatase activity was unchanged in genistein treated endometrial stromal cell cultures from women with endometriosis $(n=11)$. The control bar represents the aromatase activity from the vehicle treated cells from each of the patients and the data bars represent the aromatase activity of the cells following treatment with genistein represented as percent of control. The control value has arbitrarily been set to $100 \%$ and data are presented as the mean \pm SEM.

greater than $99 \%$ endometrial stromal cells (data not shown).

Phytoestrogen treatment did not attenuate aromatase activity in ESC from women with endometriosis $(n=11)$ at any concentration tested (Fig. 3). However, genistein $\left(10^{-9}-10^{-6} \mathrm{M}\right)$ treatment of ESC from women without endometriosis $(n=7)$ resulted in a significant increase in aromatase activity $(P<0.05)$ to approximately $150 \%$ above the activity observed in untreated ESC from the same patient (Fig. 4), whereas daidzein, naringenin and chrysin treatment had no effect. Furthermore, the genistein induced increase in aromatase activity was not attenuated by co-treatment with the estrogen receptor antagonist ICI 182,780 $(P>0.1$, Fig. 5).

\subsection{Immunocytochemistry}

Immunopositive aromatase staining was evident as a diffuse brown cytoplasmic pre- cipitate (Fig. 6) that was absent in control cultures where the primary antibody was substituted with non-immune serum. Immunopositive staining was focally present in some but not all genistein $\left(10^{-6} \mathrm{M}\right)$ treated ESC from eutopic endometrium of women without endometriosis. Moreover, no immunoreactive aromatase staining was visible in the untreated ESC taken from the same patient.

\section{DISCUSSION}

The objective of the current study was to screen dietary phytoestrogens for their ability to inhibit human recombinant aromatase activity and to determine the effect of dietary phytoestrogens on endometrial stromal cell aromatase activity in culture. Although naringenin and chrysin inhibited aromatase in our cell-free assay, they were ineffective in endometrial stromal cell cultures from 


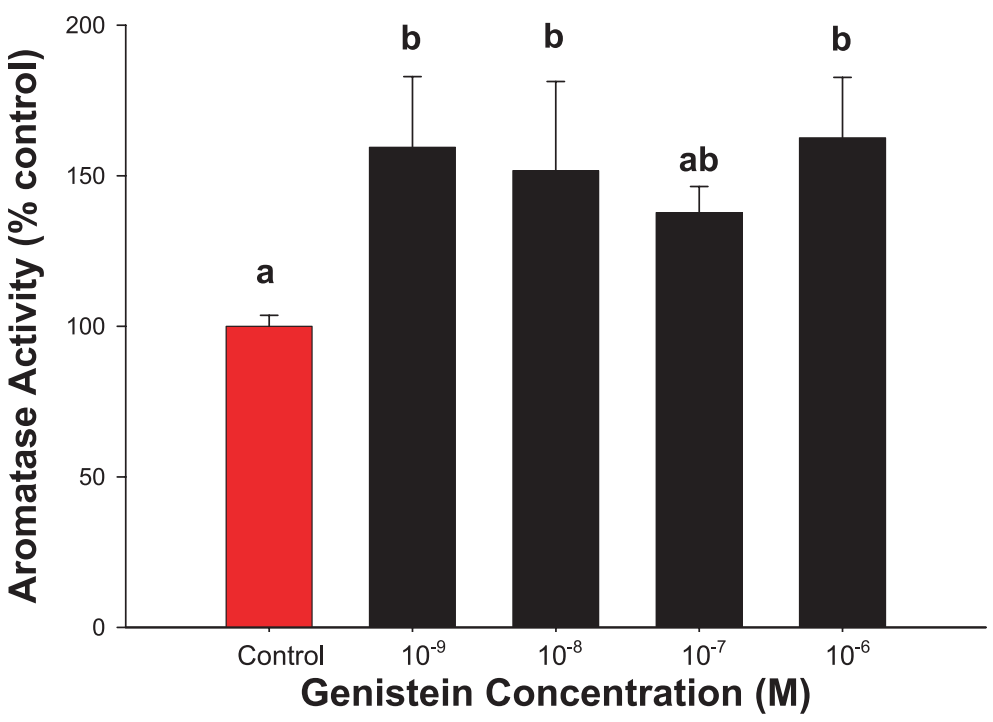

Figure 4. The effects of genistein treatment for $24 \mathrm{~h}$ on aromatase activity in endometrial stromal cells obtained from eutopic endometrium of women without endometriosis $(n=7)$. The control bar represents the aromatase activity from the untreated cells from each of the patients and the data bars represent the aromatase activity of the cells following treatment with genistein represented as percent of control. The results are the mean $( \pm$ SEM) from seven different cultures. Values with different superscripts are significantly $(P<0.05)$ different.

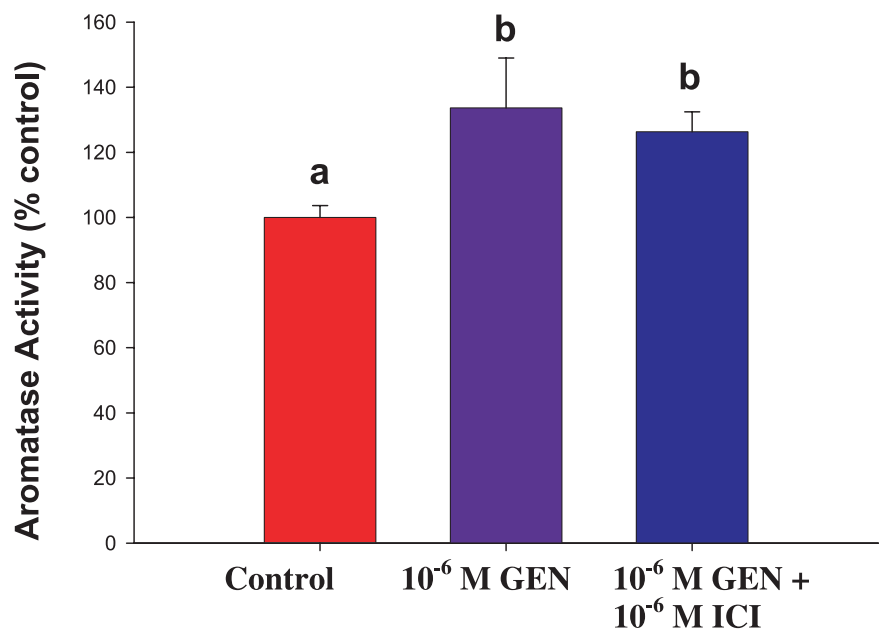

Figure 5. The effects of $10^{-6} \mathrm{M}$ genistein (GEN) alone and in combination with $10^{-6} \mathrm{M}$ ICI 182780 (ICI), and non-selective estrogen receptor antagonist, on aromatase activity obtained from the eutopic endometrium of women without endometriosis $(n=3)$. The results are the mean $( \pm$ SEM) from three different cultures. Means identified with a different letter were significantly different $(P=$ $0.008)$. 

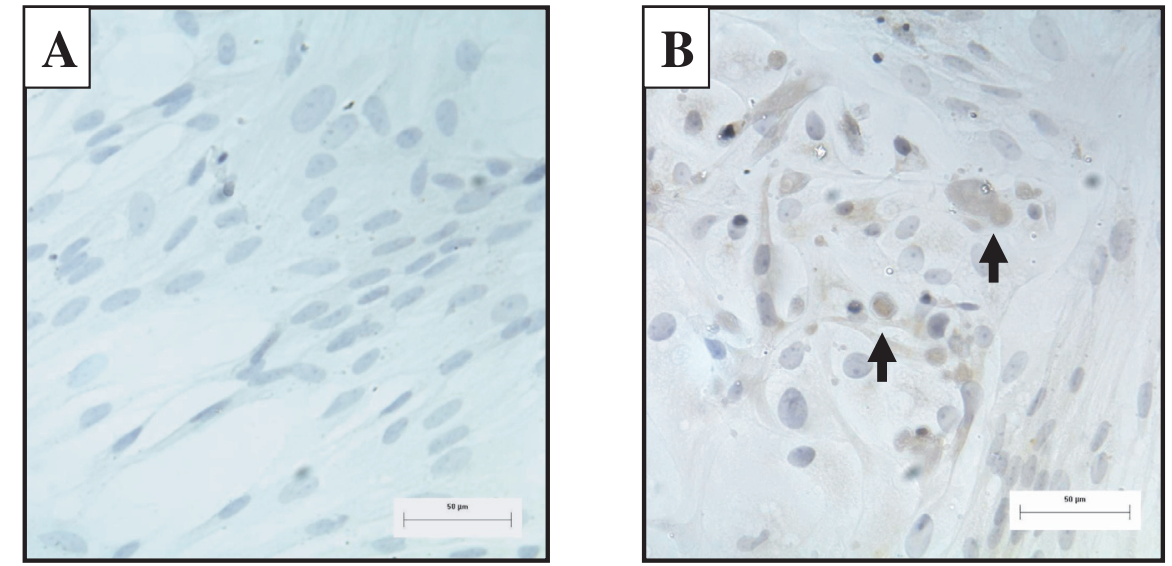

Figure 6. Immunocytochemical staining for aromatase in untreated cells $(\mathbf{A})$ and cells treated with $10^{-6} \mathrm{M}$ genistein (B) reveals positive staining in the treated cells (arrows).

women with and without endometriosis and thus are unlikely to have any potential therapeutic benefit in the management of endometriosis. In contrast, genistein, the dominant isoflavone found in soy-based foods, was inactive in the cell-free assay but to our surprise increased aromatase activity in endometrial stromal cells of women without endometriosis. These data suggest that the observed effects of genistein are not mediated through direct effects of genistein on enzyme activity but indirectly via enhanced aromatase expression in endometrial stromal cells or via intermediates on aromatase activity. This point is supported by evidence of immunocytochemical staining for aromatase in genistein treated but not untreated cells. In our study, the concentrations of genistein that were used to treat the human endometrial stromal cells ( $1 \mathrm{nM}$ to $10 \mathrm{mM}$ ) correspond to the serum concentrations of both Asian and Caucasian women who are consuming soy-based foods [27-29] and thus are considered to be physiologically relevant. Taken together, our results suggest that while phytoestrogens may have health benefits such as the proposed protection against breast cancer development $[11,12]$, genistein is unlikely to have any therapeutic value in the management of endometriosis and more importantly may increase aromatase activity in the endometrium and thus could be an important factor in the pathobiology of this enigmatic disease.

In the present study, aromatase was not detected by immunohistochemistry in control cultures of endometrial stromal cells from women without endometriosis. In addition, aromatase activity of vehicle treated endometrial cells was at background levels for the assay and thus supports the view that aromatase is either absent or inhibited in the endometrium from women without endometriosis. Our findings are in agreement with prior studies in which aromatase cytochrome $\mathrm{P} 450$ has been reported to be expressed in the endometrium of women with endometriosis but is either absent [4], or expressed at low levels in the endometrium of women without endometriosis [30]. Therefore, the patients in the current study were grouped into two categories: endometriotic and non-endometriotic. None of the phytoestrogens tested inhibited aromatase activity of the ESC from women with endometriosis. However, in the current study, genistein-treatment of 
ESC from women without endometriosis induced an increase in aromatase activity to $150 \%$ of the untreated controls similar to the findings using adrenocortical carcinoma cell lines treated with herbicides [31, 32]. Furthermore, our results are harmonious with the previous finding that genistein $(30 \mu \mathrm{M})$ increased aromatase activity 3 fold in the H295R human adrenocortical carcinoma cell line [33]. Hence, genistein treatment-induced changes in aromatase activity could lead to increased local levels of estrogens in the endometrium. However, the functional significance of genistein induced changes in aromatase activity is unknown. A previous study has demonstrated that genistein treatment increased cell proliferation and was weakly estrogenic in endometrial stromal cell and Ishikawa cell cultures [34]. However, genistein treatment antagonized the effects of estradiol in these cultures suggesting that genistein is a competitive antagonist of estradiol. Therefore, a genistein induced increase in aromatase activity and local estrogen production in the endometrium could be relevant in hypoestrogenic states such as menopause. While genistein treatment was without effect on the endometrium of macaque monkeys with surgically induced menopause [35], our proposal is supported by the observation that endometrial hyperplasia was significantly more prevalent in postmenopausal women receiving soy tablets vs. a reference group that received a placebo [36]. Moreover, a recent study [37] has also shown that high dose phytoestrogens can reverse the antiestrogenic effects of clomiphene citrate on the endometrium. Hence, we propose that the effects of soy isoflavones, including genistein on the endometrium is complex and requires further study.

The mechanism through which genistein treatment increased aromatase activity in the endometrium remains unknown. Although estradiol has been shown to increase aromatase activity in ESC cultures [38], several distinct lines of evidence lead us to suggest that genistein is not acting through an estrogen receptor mediated pathway in our cultures to increase aromatase activity. Genistein is a preferential estrogen receptor (ER)- $\beta$ agonist and has been shown to have estrogenic actions in a variety of tissues in the rat $[39,40]$. However, ER- $\alpha$, not ER- $\beta$ is the dominant ER sub-type expressed in the endometrium [41]. Furthermore, it is unlikely that genistein causes stimulation of aromatase in the endometrium by acting through a functional estrogen receptor pathway because we have shown that the stimulation of aromatase in ESC by genistein is not attenuated by co-treatment of the cells with ICI 182,780 which is a non-selective estrogen receptor antagonist. We therefore propose that it is unlikely that genistein stimulates aromatase activity in endometrial stromal cell cultures by acting directly via the ER. Alternatively, we propose that genistein can stimulate aromatase activity in the endometrium through inhibition of phosphodiesterase activity and result in increased levels of cAMP. Support for this proposal comes from evidence that genistein inhibits cAMP-phosphodiesterase activity in a variety of cell types [42-44]. In addition, aromatase expression in the endometrium is regulated through cAMPinduced promoter II [45] and cAMP-treatment has previously been shown to result in a 26-60 fold increase in endometrial aromatase activity [46].

Soy products are widely believed by the public to provide health benefits. The Food and Drug Administration has released an approval for foods that contain at least $6.25 \mathrm{~g}$ of soy protein/serving to contain a cardiovascular health claim (November 10, 1999; No. 279) and this has led to a plethora of soy-based and fortified foods as well as soy supplements to emerge on to the market [47]. Phytoestrogens are efficiently absorbed after ingestion and their bioavailability is high enough to have biological effects [48]. Furthermore, contemporary studies reveal that non-Asian women are ingesting increasing amounts of phytoestrogens in their diet as part of a trend towards a healthier lifestyle $[49,50]$. Despite potential health benefits for women of some age groups, we speculate 
that genistein consumption by women of reproductive age may have associated health risks. Moreover, epidemiological evidence demonstrates that Oriental women have a higher incidence of endometriosis than Caucasian women suggesting a link between endometriosis and dietary phytoestrogens, as Asian diets are high in soy isoflavones $[51,52]$. Hence, consumption of soy products by women of reproductive age may not be without consequence for endometrial aromatase activity and potentially endometriosis.

In summary, the results of this study demonstrate that dietary compounds, such as genistein which is present in foods including soy milk and tofu that the general public views as healthy alternatives to traditional foods in the North American diet, can increase the local production of estrogen in the ESC. Genistein-induced changes in endometrial aromatase activity may have detrimental effects which could lead to increased risk for estrogen-dependent diseases which involve the dysregulation of aromatase such as endometriosis, adenomyosis and uterine leiomyomas.

\section{ACKNOWLEDGEMENTS}

The authors gratefully acknowledge the technical assistance of Mary Louise Beecroft, RN Scott Phillips and Vasko (Bill) Georgievski. This study was supported by funding from the Canadian Network of Toxicology Centres (WGF) and the Canadian Institutes of Health Research (MOP 62681; WGF and ACH).

\section{REFERENCES}

[1] Maggiolini M, Carpino A, Bonofiglio D, Pezzi V, Rago V, Marsico S, Picard D, Ando $\mathrm{S}$. The direct proliferative stimulus of dehydroepiandrosterone on MCF7 breast cancer cells is potentiated by overexpression of aromatase. Mol Cell Endocrinol 2001, 184: $163-$ 171.

[2] Sasano H, Harada N. Intratumoral aromatase in human breast, endometrial, and ovarian malignancies. Endocr Rev 1998, 19: 593-607.
[3] Noble LS, Simpson ER, Johns A, Bulun SE. Aromatase expression in endometriosis. J Clin Endocrinol Metab 1996, 81: 174-179.

[4] Kitawaki J, Noguchi T, Amatsu T, Maeda K, Tsukamoto K, Yamamoto T, Fushiki S, Osawa Y, Honjo H. Expression of aromatase cytochrome P450 protein and messenger ribonucleic acid in human endometriotic and adenomyotic tissues but not in normal endometrium. Biol Reprod 1997, 57: 514-519.

[5] Kitawaki J, Kusuki I, Koshiba H, Tsukamoto K, Fushiki S, Honjo H. Detection of aromatase cytochrome P-450 in endometrial biopsy specimens as a diagnostic test for endometriosis. Fertil Steril 1999, 72: 1100-1106.

[6] Takayama K, Zeitoun K, Gunby RT, Sasano $\mathrm{H}$, Carr BR, Bulun SE. Treatment of severe post menopausal endometriosis with an aromatase inhibitor. Fertil Steril 1998, 69: 709-713.

[7] Dizerega GS, Barber DL, Hodgen GD. Endometriosis: role of ovarian steroids in initiation, maintenance, and suppression. Fertil Steril 1980, 33: 649-653.

[8] Kitawaki J, Kado N, Ishihara H, Koshiba H, Kitaoka Y, Honjo H. Endometriosis: the pathophysiology as an estrogen-dependent disease. J Steroid Biochem Mol Biol 2003, 83: 149-155.

[9] Rice VA. Conventional medical therapies for endometriosis. Ann N Y Acad Sci 2002, 955: 343-352.

[10] Ajossa S, Mais V, Guerrierero S, Paoletti AM, Caffiero A, Murgia C, Melis GB. The prevalence of endometriosis in premenopausal women undergoing gynecological surgery. Clin Exp Obstet Gynecol 1994, 21: 195-197.

[11] Hilakivi-Clarke L, Cho E, De Assis S, Olivo S, Ealley E, Bouker KB, Welch JN, Kan G, Clarke R, Cabanes A. Maternal and prepubertal diet, mammary development and breast cancer risk. J Nutr 2001, 131: 154S-157S.

[12] Katadre M, Osborne M, Telang NT. Soy isoflavone genistein modulates cell cycle progression and induces apoptosis in HER-2/neu oncogene expressing human breast epithelial cells. Int J Oncol 2002, 21: 809-815.

[13] Hale G, Bievre M, Hughes C. Exploring the role of progestins and phytoestrogens in menopause. Integr Med. 1999, 2: 133-141.

[14] Vincent A, Fitzpatrick LA. Soy isoflavones: are they useful in menopause? Mayo Clin Proc 2000, 75: 1174-1184.

[15] Campbell DR, Kurzer MS. Flavonoid inhibition of aromatase enzyme activity in human preadipocytes. J Steroid Biochem Mol Biol 1993, 46: 381-388. 
[16] Adlercreutz H, Bannwart C, Wahala K, Makela T, Brunow G, Hase T, Arosemena PJ, Kellis Jr. JT, Vickery LE. Inhibition of human aromatase by mammalian lignans and isoflavonoid phytoestrogens. J Steroid Biochem Mol Biol 1993, 44: 147-153.

[17] Celec P, Ostatnikova D, Caganova M, Zuchova S, Hodosy J, Putz Z, Bernadic M, Kudela M. Endocrine and cognitive effects of short-time soybean consumption in women. Gynecol Obstet Invest 2004, 59: 62-66.

[18] Tham DM, Gardner CD, Haskell WL. Potential health benefits of dietary phytoestrogens: a review of the clinical, epidemiological, and mechanistic evidence. J Clin Endocrinol Metab 1998, 83: 2223-2235.

[19] Kao Y, Zhou C, Sherman M, Laughton CA, Chen S. Molecular basis of the inhibition of human aromatase (estrogen synthetase) by flavone and isoflavones phytoestrogens: a site-directed mutagenesis study. Environ Health Perspect 1998, 106: 85-92.

[20] Jeong HJ, Shin YG, Kim IH, Pezzuto JM. Inhibition of aromatase activity by flavonoids. Arch Pharm Res 1999, 22: 309-312.

[21] Simpson ER, Zhao Y, Agarwal VR, Michael MD, Bulun SE, Hinshelwood MM, GrahamLorence S, Sun T, Fisher CR, Qin K, Mendelson CR. Aromatase Expression in Health and Disease. Recent Prog Horm Res 1997, 52: 185-213.

[22] Stresser DM, Turner SD, McNamara J, Stocker P, Miller VP, Crespi CL, Patten CJ. A high-throughput screen to identify inhibitors of aromatase (CYP19). Anal Biochem 2000, 284: 427-430.

[23] Cheng Y, Prusoff WH. Relationship between the inhibition constant $\left(\mathrm{K}_{\mathrm{I}}\right)$ and the concentration of inhibitor which causes 50 per cent inhibition $\left(\mathrm{I}_{50}\right)$ of an enzymatic reaction. Biochem Pharmacol 1973, 22: 3099-3108.

[24] Arnold JT, Kaufman DG, Seppälä M, Lessey BA. Endometrial stromal cells regulate epithelial cell growth in vitro: a new co-culture model. Hum Reprod 2001, 16: 836-845.

[25] Garzo VG, Dorrington JH. Aromatase activity in human granulosa cells during follicular development and the modulation by folliclestimulating hormone and insulin. Am J Obstet Gynecol 1984, 148: 657-662.

[26] Brodie AM, Shwarzel WC, Shaikh AA, Brodie HJ. The effect of an aromatase inhibitor, 4-hydroxy-4-androstene-3,17-dione, on estrogen-dependent processes in reproduction and breast cancer. Endocrinology 1977, 100: 1684-1695.

[27] Valentin-Blasini L, Blount BC, Caudill SP, Needham LL. Urinary and serum concentra- tions of seven phytoestrogens in a human reference population subset. J Exp Anal Environ Epidemiol 2003, 13: 276-282.

[28] Fanti P, Stephenson TJ, Kaariainen IM, Rezkalla B, Tsukamoto Y, Morishita T, Nomura M, Kitiyakara C, Custer LJ, Franke AA. Serum isoflavones and soya food intake in Japanese, Thai and American end-stage renal disease patients on chronic haemodialysis. Nephrol Dial Transplant 2003, 18: 18621868

[29] Grace PB, Taylor JI, Botting NP, Fryatt T, Oldfield MF, Al-Maharik N, Bingham SA. Quantification of isoflavones and lignans in serum using isotope dilution liquid chromatography/tandem mass spectrometry. Rapid Commun Mass Spectrom 2003, 17: 1350-1357.

[30] Taga S, Yoshida N, Sekiba K. Distribution and cyclic change of aromatase cytochrome P450 activity in human uteri. J Steroid Biochem Mol Biol 1990, 37: 741-745.

[31] Sanderson JT, Seinen W, Giesy JP, van den Berg M. 2-chloro-s-triazine herbicides induce aromatase (CYP19) activity in H295R human adrenocortical carcinoma cells: A novel mechanism for estrogenicity. Toxicol Sci 2000, 54: 121-127.

[32] Sanderson JT, Boerma J, Lansbergen GW, den Berg M. Induction and inhibition of aromatase (CYP19) activity by various classes of pesticides in H295R human adrenocortical carcinoma cells. Toxicol Appl Pharmacol 2002, 182: 44-54.

[33] Sanderson JT, Hordijk J, Denison MS, Springsteel MF, Nantz MH, van den Berg M. Induction and inhibition of aromatase (CYP19) activity by natural and synthetic flavonoid compounds in H295R human adrenocortical carcinoma cells. Toxicol Sci 2004, 82: 70-79.

[34] Kayisli UA, Aksu CAH, Berkkanoglu M, Arici A. Estrogenicity of isoflavones on human endometrial stromal and glandular cells. J Clin Endocrinol Metab 2002, 87: 5539-5544.

[35] Foth D, Cline JM. Effects of mammalian and plant estrogens on mammary glands and uteri of macaques. Am J Clin Nutr 1998, 68: 1413S-1417S.

[36] Unfer V, Casini ML, Costabile L, Mignosa M, Gerli S, Di Renzo GC. Endometrial effects of long-term treatment with phytoestrogens a randomized, double-blind, placebo-controlled study. Fertil Steril 2004, 82: 145-148.

[37] Unfer V, Casini ML, Costabile L, Mignosa M, Gerli S, Di Renzo GC. High dose of phytoestrogens can reverse the antiestrogenic effects of clomiphene citrate on the endometrium in 
patients undergoing intrauterine insemination: A randomized trial. J Soc Gynecol Investig 2004, 11: 322-328.

[38] Bulun SE, Yang S, Fang Z, Gurates B, Tamura M, Sebastian S. Estrogen production and metabolism in endometriosis. Ann N Y Acad Sci 2002, 955: 75-85.

[39] Santell RC, Chang YC, Nair MG, Helferich WG. Dietary genistein exerts estrogenic effects upon the uterus, mammary gland and the hypothalamic/pituitary axis in rats. J Nutr 1997, 127: 263-269.

[40] Diel P, Smolnikar K, Schulz T, LaudenbachLeschowski U, Michna H, Vollmer G. Phytoestrogens and carcinogenesis-differential effects of genistein in experimental models of normal and malignant rat endometrium. Hum Reprod 2001, 16: 997-1006.

[41] Weihua Z, Saji S, Makinen S, Cheng G, Jenson EV, Warner M, Gustafsson J. Estrogen receptor (ER) $\beta$, a modulator of $E R \alpha$ in the uterus. PNAS 2000, 97: 5936-5941.

[42] Kuppusamy UR, Das NP. Effects of flavonoids on cyclic AMP phosphodiesterase and lipid mobilization in rat adipocytes. Biochem Pharmacol 1992, 44: 1307-1315.

[43] Nichols MR, Morimoto BH. Tyrosine kinaseindependent inhibition of cyclic-AMP phosphodiesterase by genistein and tyrphostin 51 . Arch Biochem Biophys 1999, 366: 224-230.

[44] Burvall KM, Palmberg L, Larsson K. The tyrosine kinase inhibitor genistein increases basal cAMP and potentiates forskolininduced cAMP accumulation in A549 human airway epithelial cells. Mol Cell Biochem 2002, 240: 131-133.
[45] Sofi M, Young MJ, Papamakarios T, Simpson ER, Clyne CD. Role of CRE-binding protein (CREB) in aromatase expression in breast adipose. Breast Cancer Res Treat 2003, 79: 399_ 407.

[46] Noble LS, Takayama K, Zeitoun KM, Putman JM, Johns DA, Hinshelwood MM, Agarwal VR, Zhao Y, Carr BR, Bulun SE. Prostaglandin $E_{2}$ stimulates aromatase expression in endometriosis-derived stromal cells. J Clin Endocrinol Metab 1997, 82: 600-606.

[47] Setchell KD, Brown NM, Desai P, ZimmerNechemias L, Wolfe BE, Brashear WT, Kirschner AS, Cassidy A, Heubi JE. Bioavailability of pure isoflavones in healthy humans and analysis of commercial soy isoflavone supplements. J Nutr 2001, 131 (Suppl): 1362S-1375S

[48] Ross JA, Kasum CM. Dietary flavonoids: bioavailability, metabolic effects, and safety. Annu Rev Nutr 2002, 22: 19-34.

[49] Goodman MT, Wilkens LR, Hankin JH, Lyu LC, Wu AH, Kolonel LN. Association of soy and fiber consumption with the risk of endometrial cancer. Am J Epidemiol 1997, 146: 294-306.

[50] Guthrie JR, Ball M, Murkies A, Dennerstein L. Dietary phytoestrogen intake in mid-life Australian-born women: relationship to health variables. Climacteric 2000, 3: 254-261.

[51] Miyazawa K. Incidence of endometriosis among Japanese women. Obstet Gynecol 1976, 48: 407-409.

[52] Arumugam K, Templeton AA. Endometriosis and race. Aust N Z J Obstet Gynaecol 1992, 32: $164-165$ 